\title{
Spiders associated with Psychotria carthagenensis Jacquin. (Rubiaceae): vegetative branches versus inflorescences, and the influence of Crematogaster sp. (Hymenoptera, Formicidae), in South-Pantanal, Brazil
}

\author{
Faria, RR.* and Lima, TN. \\ Programa de Pós-Graduação em Ecologia e Conservação, Universidade Federal do Mato Grosso do Sul - UFMS, \\ CP 549, CEP 79070-900, Campo Grande, MS, Brazil \\ *e-mail: roger.faria@yahoo.com.br
}

Received February 20, 2006 - Accepted September 13, 2006 - Distributed May 31, 2008

(With 1 figure)

\begin{abstract}
The aim of this study was to analyze: i) the spider community in vegetative and reproductive branches of Psychotria carthagenensis concerning relative abundance, guild composition and body size distribution; ii) ant abundance in diferent types of branches and iii) the spider behavior when experimentally put in contact with inflorescences covered with ants. There was no difference between vegetative and reproductive branches in relation to spider abundance, composition of guilds and body size distribution of spiders. However, there was a significant difference in ant abundance. In the behavioral experiment, $90 \%$ of the spiders were expelled from inflorescences by ants; in control treatment, $100 \%$ remained in the inflorescences. The ant density in different parts of the plant may explain the spider distribution.
\end{abstract}

Keywords: plant-dwelling spiders, guilds, body-size distribution, Psychotria sp., ant-plant interactions.

\author{
Aranhas associadas à Psychotria carthagenensis Jacq. (Rubiaceae): \\ ramos vegetativos versus inflorescências, $\mathrm{e}$ influência \\ de Crematogaster sp. (Hymenoptera, Formicidae), no Pantanal Sul, Brasil
}

\begin{abstract}
Resumo
Aranhas associadas à Psychotria carthagenensis Jacq. (Rubiaceae). O objetivo deste estudo foi analisar: i) a comunidade de aranhas em ramos vegetativos e reprodutivos de $P$. carthagenensis quanto à abundancia relativa, composição das guildas e distribuição de tamanhos; ii) a abundância de formigas nos diferentes tipos de ramos; e iii) o comportamento das aranhas quando colocadas em inflorescências cobertas por formigas. Não houve diferença significativa entre ramos vegetativos e reprodutivos em relação à composição de guildas, abundância relativa e distribuição de tamanhos de aranhas. Mas quando comparado à abundância de formigas, houve diferença. No experimento comportamental, $90 \%$ das aranhas foram expulsas das inflorescências pelas formigas; no tratamento controle; $100 \%$ das aranhas permaneceram nas inflorescências. Para $P$. carthagenensis, talvez a densidade de formigas em diferentes partes da planta explique melhor a distribuição das aranhas.
\end{abstract}

Palavras-chave: aranhas moradoras de plantas, guildas, distribuição de tamanho, Psychotria sp., interações formigaplanta.

\section{Introduction}

Spiders are scattered over almost all terrestrial environments, being more abundant in areas of rich vegetation (Foelix, 1996). In a micro-scale, the structural complexity of the plant is considered one of the main variables in determining abundance, body size distribution and formation of distinct spider guilds (Souza, 2007). The significance of habitat structure

in spider biology has been a topic of numerous ecological studies (Halaj et al., 1998), applying to several spider species in different kinds of plants in different regions (e.g. Gunnarson, 1990; Halaj et al., 1998; 2000; Ysnel and Canard, 2000; Souza and Módena, 2004; Souza and Martins, 2004; 2005; Romero and Vasconcellos-Neto, 2005). 
Branches with inflorescences are structurally distinct from vegetative branches, and may represent microhabitats with different attractions to spiders (Souza, 2007). Inflorescences are frequently highly structured habitats with high density of potential prey (e.g. herbivores and pollinators) (Nentwig, 1993). In addition, the presence of inflorescences adds another dimension to plant architecture because of the change in the microclimatic conditions and availability of refuge against predators (Souza and Módena, 2004).

Psychotria carthagenensis Jacq. (Rubiaceae) is a sub-canopy shrub occurring at Pantanal in flooding vegetation areas, "cambarazal", "capão de vazante", sand or clay soils (Pott and Pott, 1994). This species presents small white flowers with tubular corolla, gathered in cymose terminal inflorescences; has diurnal antese and is commonly pollinated by bees and butterflies, and nectar is the main resource offered (Consolaro, 2004). In this study the presence of ants of the genus Crematogaster was observed in several parts of the plant. Other studies have reported a significant presence of ants in other Psychotria species (e.g. Nentwig, 1993; Altshuler, 1999). When ants are present in plants, their predatory and pugnacious behavior towards other animals deter their access to several structures of vegetal organisms (Altshuler, 1999), which can affect principally the arthropod community structure, including the spiders (Mody and Linsenmair, 2004). The goal of this paper was to analyze: i) the spider community in vegetative and reproductive branches of $P$. carthagenensis concerning relative abundance, guild composition and body size distribution, ii) ant abundance in different types of branches, and iii) the spider behavior when put in contact with inflorescences covered with ants.

This study was carried out from $1^{\text {st }}$ to $4^{\text {th }}$ of October 2005 , in two fragments of forest gallery located in the vicinity of "Base de Estudos do Pantanal (BEP)", "Pantanal do Miranda", Central Brazil (19 ${ }^{\circ} 34^{\prime} \mathrm{S}$ and $\left.57^{\circ} 00^{\prime} \mathrm{W}\right)$. Thirty plants were surveyed in total; 60 branches, two per plant. In each plant, one collector sampled a flowered branch and the other a vegetative branch, both using plastic bags measuring $0.60 \times 0.40 \mathrm{~m}$. The branches were approximately $0.40 \mathrm{~m}$ long and were $1.50 \mathrm{~m}$ above ground. The bagged branches were cut with pruning scissors and packed in bags sealed with adhesive tape. The sample inside the plastic bags was stored in a freezer $\left(-5{ }^{\circ} \mathrm{C}\right)$ for 12 hours before examination in the laboratory. Each spider was measured (length chelicerae-fianders in millimeters) and stored in alcohol at $70 \%$. The spider species were then identified by specialists. The spiders were classified in guilds according to Uetz et al. (1999). The relative abundance of ants among vegetative and reproductive branches was estimated using similar methods to those which were previously carried out with the spiders. From flowered branches, only the inflorescence was collected, and from vegetative branches, the extremity was collected (about $10 \mathrm{~cm}$ ).
There were two treatments to verify agonistic interactions between spiders and ants: inflorescences with ants and inflorescences without ants. Each treatment was carried out by placing one spider per inflorescence and its behavior in relation to ants was observed. The spider that stayed on the branch up to five minutes was considered "established" and the spider that escaped before five minutes was considered "non-established". Ten repetitions were made. All spiders used in the experiment were collected with the entomological beater method with aid of a puçá; all spiders belonged to the Pisauridae family and were approximately $3 \mathrm{~mm}$ long. This family was chosen because these spiders were more common in samples for comparison between vegetative and reproductive branches.

The relative abundance of ants and spiders between treatments was compared using Student $t$-test (SYSTAT 10 software). The guild composition was analyzed using the Morisita-Horm (BIO-DAP software) quantitative index of similarity, whose values vary from 0 to 1 , in order to compare guild composition between microhabitats. The distribution of sizes between these two types of branches was compared by Confidence Intervals at $95 \%$ analysis. Specimens of spiders were deposited at the "Instituto Butantã - Laboratório de Artrópodes", and ants at the "Coleção de Referência Zoológica da Universidade Federal do Mato Grosso do Sul”.

\section{Results and Discussion}

\subsection{Spider community}

The total amount of spiders collected was 71, 30 from reproductive and 41 from vegetative branches. There was no difference in the comparison between the average values of spider number in vegetative $($ Mean $=1.41 ; \mathrm{SD}=1.268)$ and reproductive (Mean $=1 ; \mathrm{SD}=1.462)$ branches of $P$. carthagenensis $(\mathrm{t}=-1.076 ; \mathrm{df}=28 ; \mathrm{p}=0.291)$. One spider of vegetative branch and five ones of reproductive could not be identified. The presence of inflorescence in P. carthagenensis had no significant effect on spider abundance. Even the presence of flowers with different size structures and designs, when compared with vegetative branches, was not sufficient for spiders to be more abundant in flowering branches. Romero and Vasconcellos-Neto (2005), using artificial inflorescences in Bromelia balansae Mez, found a spider colonization rate slower than that without inflorescences. In the case of Bromelia balansae, the presence of the inflorescence provokes a change in the arrangement of the rosettes which consequently interferes in the availability of potential prey that fall in the bromeliad. The results of the present paper seem to contrast with those obtained by Souza and Martins (2004), which found that the number of spiders both in natural and artificial inflorescences was greater than in vegetative branches. In this study, the presence of inflorescence represented an increase in the ant density, and the low 
density of ants in vegetative branches can explain the reason of more spiders on these branches.

Spiders of the families Theridiidae, Pisauridae, Araneidae and Anyphaenidae were identified up to the possible taxonomic level. All members of Dictynidae are of the genus Dictyna. Mimetidae are two genera, Ero sp. and Gelanor sp., and the others were not identified. Salticidae are Cilystella sp. and Cotinusa sp., and the others not identified. In the reproductive branches the most frequent families were Pisauridae $(68 \%)$, followed by Salticidae, Mimetidae and Anyphaenidae ( $8 \%$ each), and the least frequent were Dyctinidae and Theridiidae ( $2 \%$ each); Araneidae was absent. In vegetative branches the Pisauridae was also predominant (72\%), followed by Salticidae (15\%), Anyphaenidae (7.5\%), Mimetidae and Araneidae (2.5\% each); Theridiidae and Dyctinidae were absent. According to Morisita-Horm index, guild composition in the different types of branches was similar $(0,995)$, which indicates high similarity between habitats. Web-building guild was the least frequent in both branches, and ambushers were the most frequent in both treatments, followed by stalkers and foliage runners (Figure 1). Body size distribution of the two branch types did not differ. In vegetative branches the smallest body size value found was $1 \mathrm{~mm}$ and the greatest, $5.5 \mathrm{~mm} ; 50 \%$ of the spiders in this treatment measured between $2.5 \mathrm{~mm}$ and $4.0 \mathrm{~mm}$. In reproductive branches the smallest body size was $1.5 \mathrm{~mm}$ and the greatest, $5.0 \mathrm{~mm} ; 50 \%$ of the spiders in this treatment measured between $2.0 \mathrm{~mm}$ and $3.5 \mathrm{~mm}$. The body size distributions show overlap in confidence intervals at $95 \%$ : vegetative $=3.44-2.71 \mathrm{~mm}$ and reproductive $=3.41-2.66 \mathrm{~mm}$. The presence of inflorescence did not represent a distinct guild composition and body size distribution. The high frequency of ambushers was expected in flowering branches, because spiders from this guild belong to the Thomisidae family, typical of inflorescences (Nentwig, 1993; Souza and Módena, 2004;

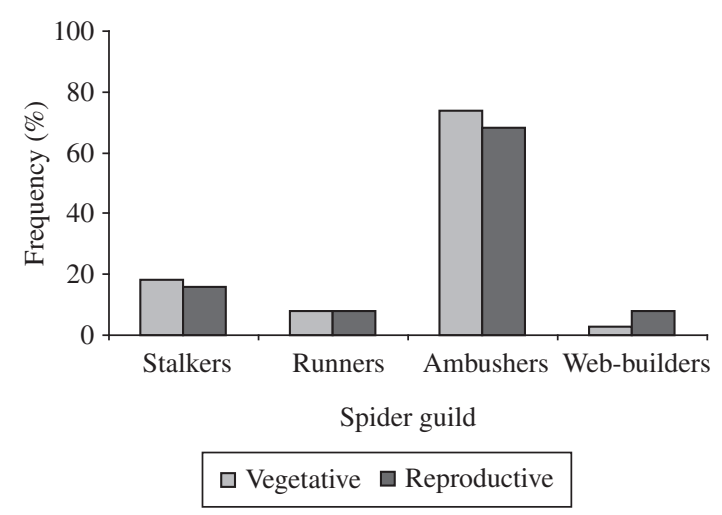

Figure 1. Frequency of stalking, foliage running, ambushing and web-building guild in vegetative and reproductive branches of $P$. carthagenensis, South-Pantanal, Central Brazil.
Souza and Martins, 2004; Souza, in press). This result may be the best indicator that some factor is interfering in the spider community.

\subsection{Influence of ants}

Of 193 ants sampled, 138 were from flowered branches $($ Mean $=4.6 ; \mathrm{SD}=6.447)$ and 55 from vegetative branches $($ Mean $=1.833 ; \mathrm{SD}=3.119)$. The average relative abundance of ants differed significantly when compared between treatments $(t=2.517 ; \mathrm{df}=29 ; \mathrm{p}=0.018)$. In the experiment carried out to verify the spiders' behavior towards ants, $100 \%(\mathrm{n}=10)$ of the spiders remained in the inflorescences in control treatment. In the treatment of inflorescences with ants, $90 \%(n=9)$ of the spiders were expelled and only $10 \%(n=1)$ remained in the inflorescence. This spider in particular was particularly trapped in the inflorescence in a region above which the ants had been circulating.

Since the inflorescences were densely occupied by ants, we suggest that ants, which affected Pisauridae in our experiment, may be influencing the distribution of all members of the spider community. According to Mody and Linsenmair (2004) and Izzo and Vasconcelos (2005), ants clearly reduce the arthropod density, like herbivores and important predators such as spiders. Halaj et al. (1997) also found a strong interaction between spiders and ants, with spider displacement by ants. The reduction of spiders by the ants represents a contrast with other studies, which show a null or a positive correlation between spider and ant numbers (Grant and Moran, 1986; Karhu, 1998). In the case of $P$. carthagenensis, there is an indication of a negative effect, because ants may displace both the spiders and their potential prey. The ant density in different parts of the plant may explain better the distribution of the spiders and their potential prey.

Acknowledgements - We convey our thanks to the teachers E.A. Fisher and G. Graciolli for their suggestions; F.A.M. Santos for the help in the analysis; A.L.T. Souza for the comments and the bibliography; G.R. Giraldelli for the help in field; A.D. Brescovit for spider identification; I. Leal and C.R.F. Brandão for their help with Crematogaster; D. Rossi and Prof. R. Vieira for text revision; to the organizers and participants of the Field Ecology Course "Ecologia do Pantanal - 2005" for logistic support and discussions; and to the anonymous referees for their valuable comments on the manuscript. The first author had a fellowship from Conservation International-Brazil and the second from CAPES.

\section{References}

ALTSHULER, DL., 1999. Novel interactions of non-pollinating ants with pollinators and fruit consumers in a tropical forest. Oecologia, vol. 119, no. 4, p. 600-606.

BIODAP software. Diversity Ecological and Its Measurements. Fundy National Park and Parks Canada (PHQ). (http://nhsbig. inhs.uiuc.edu accessed in 20/04/2005).

CONSOLARO, HN., 2004. Biologia reprodutiva de duas espécies de Rubiaceae em matas de galeria do Triangulo 
Mineiro-MG. (Dissertação de Mestrado) - UFU, UberlândiaMG. 58 p.

FOELIX, RF., 1996. Biology of spiders. Oxford: Oxford University Press. 2 ed. 330 p.

GRANT, S. and MORAN, VC., 1986. The effects of foraging ants on arboreal insect herbivores in an undisturbed woodland savanna. Ecological Entomology, vol. 11, no. 1, p. 83-93.

GUNNARSSON, B., 1990. Vegetation structure and the abundance and size distribution of spruce-living spiders. Journal of Animal Ecology, vol. 59, no. 2, p. 743-752.

HALAJ, J., ROSS, DW. and MOLDENKE, AR., 1997. Negative effects of ant foraging on spiders in Douglas-fir canopies. Oecologia, vol. 109, no. 2, p. 313-322.

-, 1998. Habitat structure and prey availability as redictors of the abundance and community organization of spiders in western Oregon forest canopies. The Journal of Arachnology, vol. 26, no. 2, p. 203-20.

IZZO, TJ. and VASCONCELOS, HL., 2005. Ants and plant size shape the structure of the arthropod community of Hirtella myrmecophila, an Amazonian ant-plant. Ecological Entomology, vol. 30 , no. 6 , p. 650-656.

KARHU, KJ., 1998. Effects of ant exclusion during outbreaks of a defoliator and a sap-sucker on birch. Ecological Entomology, vol. 23 , no. 2, p. 185-194.

MODY, K. and LINSENMAIR, KE., 2004. Plant-attracted ants affect arthropod community structure but not necessarily herbivory. Ecological Entomology, vol. 29, no. 2, p. 217-225.

NENTWIG, W., 1993. Spiders of Panama. Biogeography, investigation, phenology, check list, key and bibliography of a tropical spider fauna. Fauna and Flora Handbook no. 12. Gainesville, USA: Sandhill Crane Press. 247p.

POTT, A. and POTT, VJ., 1994. Plantas do Pantanal. $1^{\text {a }}$ ed. Mato Grosso do Sul: Embrapa, Corumbá. 320p.

ROMERO, GQ., and VASCONCELLOS-NETO, J., 2005. The effects of plant structure on the spatial and microspatial distribution of a bromeliad-living jumping spider (Salticidae). Journal of Animal Ecology, vol. 74, no. 1, p. 12-21.

SOUZA, ALT., 2007. Influência da estrutura do habitat na distribuição de aranhas. In GONZAGA, MO., JAPAYASSÚ, HF. and SANTOS, AJ. (eds). Ecologia e Comportamento de aranhas, ed. Interciencia. Rio de Janeiro, 400 p.

SOUZA, ALT. and MARTINS, RP., 2004. Distribution of plantdwelling spiders: inflorescences versus vegetative branches. Austral Ecology, vol. 29, no. 6, p. 342-349.

-, 2005. Foliage density of branches and distribution of plantdwelling spiders. Biotropica, vol. 37, no. 3, p. 416-420.

SOUZA, ALT. and MÓDENA, ES., 2004. Distribution of spiders on different types of inflorescences in the Brazilian Pantanal. The Journal of Arachnology, vol. 32, no. 2, p. 345-348.

SYSTAT software. Version 10, 2000. SPSS Inc.

UETZ, GW., HALAJ, J. and CADY AB., 1999. Guild structure of spiders in major crops. The Journal of Arachnology, vol. 27, no. 1 , p. $270-280$.

YSNEL, F. and CANARD, A., 2000. Spider biodiversity in connection with the vegetation structure and the foliage orientation of hedges. The Journal of Arachnology, vol. 28, p. $107-114$. 